$1-2020$

\title{
On Emotions and the Politics of Attention in Judicial Reasoning
}

Emily Kidd White

\section{Source Publication:}

Virtue, Emotion and Imagination in Law and Legal Reasoning. Ed. Amalia Amaya and Maksymilian Del Mar. Oxford: Hart Publishing, 2020. 101-120.

Follow this and additional works at: https://digitalcommons.osgoode.yorku.ca/scholarly_works

Part of the Law and Philosophy Commons, Legal Ethics and Professional Responsibility Commons, and the Legal Theory Commons 


\section{B L O O M S B U R Y COLLECTIONS

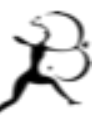

White, Emily Kidd. "On Emotions and the Politics of Attention in Judicial Reasoning." Virtue, Emotion and Imagination in Law and Legal Reasoning. Ed. Amalia Amaya and Maksymilian Del Mar. Oxford: Hart Publishing, 2020. 101-120. Bloomsbury Collections. Web. 16 Jun. 2020. $<$ http://dx.doi.org/10.5040/9781509925162.ch-006>.

Downloaded from Bloomsbury Collections, www.bloomsburycollections.com, 16 June 2020, 15:16 UTC.

Access provided by: York University

Copyright $($ The editors and contributors severally 2020. All rights reserved. Further reproduction or distribution is prohibited without prior permission in writing from the publishers. 


\section{6}

\section{On Emotions and the Politics of Attention in Judicial Reasoning}

EMILY KIDD WHITE*

\section{Introduction}

If you catch him,

Hold up a flashlight to his eye. It's all dark pupil,

an entire night itself, whose haired horizon tightens

as he stares back, and closes up the eye. Then from the lids

one tear, his only possession, like the bee's sting, slips.

Slyly he palms it, and if you're not paying attention

he'll swallow it. However, if you watch, he'll hand it over,

cool as from underground springs and pure enough to drink.

'Man-Moth', Elizabeth Bishop, The Complete Poems 1926-1979

Legal doctrine regularly requires judges to both understand and use emotions in different ways. ${ }^{1}$ This chapter explores the role of emotions in fixing and sustaining judicial attention on the impact of a law on the constitutional rights of an individual or group. ${ }^{2}$ That certain forms of wrong or harm, including forms of political

\footnotetext{
* This chapter was presented at the 'Virtue, Emotion and Imagination in Legal Reasoning' colloquium, convened by Amalia Amaya and Maksymilian Del Mar at the Universidad Nacional Autónoma de México. The author was grateful for the invitation and also to the participants and conveners, for their deep and incisive comments. An early draft was presented at New York University School of Law with Samuel Scheffler offering a series of pressing questions as the forum commentator, at the PULSE lecture series convened by Gerry Simpson at the London School of Economics, and at a panel at the Law and Society Association annual meeting in Toronto, convened by the head of the Law and Emotion Collaborative Research Network, Susan Bandes. The chapter benefitted a great deal from these interactions, and also from discussions with Jeremy Waldron.

${ }^{1}$ See White (forthcoming).

${ }^{2}$ This analysis is relevant to those constitutional law regimes where a law or government action can violate a constitutional right not only in purpose, but in effect. Judicial considerations of the impact or effects of the impugned law or government act can occur at the stage of the analysis where it is determined whether a right has been violated, and/or at the stage of the analysis where the judge must determine whether a violation is justified via a proportionality analysis. See eg White (2014), and Huscroft, Miller and Webber (2014).
} 
and social exclusion, are difficult to detect in the absence of focused attention is, I think, what Elizabeth Bishop's poem 'Man-Moth', excerpted here in epigraph, intends to express. This chapter explores the role of emotions in setting up the serious, sustained inquiry into the impact of a law on the constitutionally guaranteed rights of an individual or group that is required under various legal regimes. When named, this emotional aspect of legal reasoning is often relayed as a call for judicial empathy, ${ }^{3}$ but, as this chapter aims to show, this is neither a sufficient nor apt description of the emotionally-laden, political practice of fixing one's attention on a subject. ${ }^{4}$ Drawing on the philosophy of emotion, ${ }^{5}$ we can sketch, for example, various ways in which judicial attempts to pay attention to the claimant might go awry such that they prove anathema to core legal values, ${ }^{6}$ or fail to comport with the professional demands on the practicing judge in the adjudication of a constitutional rights case. This chapter aims to bring this aspect of legal reasoning more clearly into focus by delineating a series of ill versions of judicial attention, and so too by recognising some persistent problems with the related concept of judicial empathy, which can be roughly defined as the attempt to enter either the mind or situation of the person before the court. ${ }^{7}$

Iris Murdoch called the process of imagining a 'moral discipline of the mind', an effort comparable to that 'of "composing" and "holding" a difficult work of art in one's attention.' The focus of this chapter is on precisely these kinds of efforts of attention that are involved in legal reasoning, and its principal task is to explore how emotions motivate and facilitate the kind of attention necessary to ascertain whether a legal commitment to a right has been violated. Emotions play an integral role in the form of attention that judges must, as a matter of law, pay to the claimant in a rights case. ${ }^{9}$ For, as the chapter concludes, certain forms of constitutional reasoning require from judges a certain politics of attention (meaning here the conscientious and effortful attempt to both pay attention and effectuate a principled distribution of attention) in which emotions play indispensable roles.

\footnotetext{
${ }^{3}$ See eg Breyer (2013) and Leben (2011).

${ }^{4}$ Kind's chapter in this volume (chapter ten) offers an invaluable discussion on the complex difficulty of defining empathy in the context of judicial reasoning (Kind, 2020).

${ }^{5}$ See eg Goldie (2010), Blum (1980), De Sousa (1987), Leighton (1985), Leighton (2003), Abrams and Keren (2010), Solomon (1988), Solomon (1977), Nussbaum (1996) and Nussbaum (2001).

${ }^{6}$ As Jeremy Waldron writes, 'A legal system is a normative order, both explicitly and implicitly. Explicitly it commits itself publicly to certain rules and standards. Some of these it upholds and enforces, but for others, in certain regards, it fails to do so. The explicit content of the norms recognised by the legal system provides us with a pretty straightforward basis for saying, on these occasions, that the legal systems has fallen short of its own standards, without necessarily licensing the cynical conclusion that these were not its standards'. Waldron (2012a), 65-66.

${ }^{7}$ For a deeper discussion on this, see Kind (2020) (chapter ten in this volume).

${ }^{8}$ Murdoch (1993), 322. For a rich application of the philosophy of Iris Murdoch to the practice of judicial reasoning, see van Domselaar (2020) (chapter five in this volume).

${ }^{9}$ This chapter aims only to set to light on the overlooked emotional aspects of the judicial reasoning prescribed under some constitutional regimes (questions that set aside how this all bears out in practice). An inquiry which leaves open the possibility of distinct, even potentially competing, sets of moral or political reasons to use emotions to interact with rights claimants in other ways.
} 


\section{Two Legal Reasons for Paying Attention}

There are different sorts of ethical and political reasons for fixing one's attention on a subject, which may or may not comport with the legal reasons that judges have for doing so. ${ }^{10}$ Parsing out the legal reasons for judges to pay attention to claimants opens space for asking whether a legal system can deliver on the standards to which it has been publicly committed. Wholesale prescriptions of emotions to the judicial role pay insufficient attention to the normative situation of the law (altered necessarily by its public, institutional and coercive aspects), ${ }^{11}$ and fail to heed to both the political quality, and the structure of specific legal regimes (eg judicial empathy might be required at certain stages of a constitutional rights analysis, but unsuitable to judicial reasoning at certain stages of criminal law sentencing). ${ }^{12}$ This chapter focuses only on the emotional aspects of judicial reasoning that are required under a particular set of constitutional regimes, where judges work to determine whether the impact of a law on an individual or group amounts to a rights violation, and/or whether this violation might be justified under a form of proportionality reasoning. ${ }^{13}$ The constitutional systems in mind have two general features. First, a normative or political conception of the human person that serves as a foundational constitutional value (for the last fifty years or so, we have seen the concept of human dignity frequently take this place in a number of constitutional law regimes). ${ }^{14}$ Second, the concern here is with those legal systems that consider the impact, or effect, of a law or government action when determining whether the constitutional rights of an individual or group have been violated. ${ }^{15}$ Together, these two features offer distinct sets of role-based reasons for judges to pay a specific sort of attention - one that evidences respect and concern - to the person in the well of the court bringing forth a rights claim. The assumption that the legal values underpinning the constitutional system demand that respect be shown to the claimant, is related but distinct from the need to ascertain a technical and/or strictly cognitive understanding of the law's impact on the claimant's constitutional rights. This is because judges have role-based reasons to see human

\footnotetext{
${ }^{10}$ On legal reasoning as a distinct form of reasoning, see MacCormick (1978), and, in particular, chapter IX 'Legal Reasoning and Legal Theory'.

${ }^{11}$ The point here is simply that an emotion that facilitates perception, right action, and/or virtuous activity in daily life won't necessarily have the same effect in the context of adjudication. The social, political, and coercive aspects of law alter the ethical landscape.

${ }^{12} \mathrm{~A}$ recurring theme in the emerging law and emotions scholarship is the concern with breaking down overly general claims about both emotion and law, highlighting the need to study specific emotions within the context of specific legal regimes. See eg White (2014), Maroney (2006) and Bandes (1999).

${ }^{13}$ Eg Huscroft, Webber and Miller (2014).

${ }^{14}$ See eg Waldron (2012a), McCrudden (2008), and Kretzmer and Klein (2002).

15 'It is perfectly proper, he writes, for judges to disagree about what the Constitution requires. But it is disgraceful for an interpretation of the Constitution to be premised upon unfounded assumptions about how people live.' United States v Kras, 409 U.S. 434, 460 (1973) (Marshall, J, dissenting), cited by Corso (2014), 95.
} 
persons as bearers of a deep sort of value, ${ }^{16}$ in addition to having reasons to see them as holding valuable information concerning the impact of the legal regime under constitutional scrutiny. This latter set of reasons concern the capture of relevant information in a constitutional rights case, and, as such, are epistemic in nature. ${ }^{17}$ The former gives the judge a set of value-based reasons to pay attention to the claimant that are sourced from the value (and standing) that the law deems the claimant to possess. ${ }^{18}$

The picture, thus far, looks relatively uncomplicated. At certain stages of reasoning through a constitutional rights case, judges must make efforts to understand the experiences of the claimant under the impugned law or legal regime, and for this, something like attention, or empathy (here posited as a facet of attention), appear necessary. This prescription, however, is tricky and prone to misuse, and this chapter raises several complications with respect to the judge's ability to pay the required attention to the claimant in a rights case. This is not to say that constitutional systems would be better served were judges required to altogether abandon such efforts of attention, or related empathetic stances. ${ }^{19}$ Were this even possible, ${ }^{20}$ this would amount to an abdication of the role and responsibility assigned to the judge in the constitutional systems outlined above. ${ }^{21}$ Nevertheless, it is only after getting down into the reeds with the question that the possibility of mapping out this form of judicial reasoning emerges (and later, the possibility of holding judges accountable for errors, or, more broadly, holding a legal system accountable for laying claim to a normative or political good that it isn't set up to deliver).

\section{Errors of Attention}

Some emotions precipitate or compound an inability to pay quality attention to other persons, while other emotions play indispensable roles in fixing and holding attention on a subject. ${ }^{22}$ Simone Weil wrote of the difficulty of witnessing the suffering of another without either moving to obscure the other's pain (often by way of erasing their subjectivity, and/or lowering their status), or by entertaining some

\footnotetext{
16 'The Athenians adopted a legal principle of treating one another as equals, not because of any moral conviction about real equality between them, but because such a principle made possible a form of political community they could not otherwise have' Waldron (2012a), 20. Thus, for our purposes here, we can raise the question as to whether this political commitment mirrors a pre-existing moral commitment.

${ }^{17}$ See Elgin (2007) for a rich discussion on epistemology and understanding. See also Elgin (2020) on emotions and salience (chapter three in this volume).

${ }^{18}$ Ibid.

${ }^{19}$ See White (forthcoming). See also Zipursky (2020) (chapter four in this volume).

${ }^{20} \mathrm{On}$ the subject of this not being possible, see Gardner (2008).

${ }^{21}$ See eg White (2014). None of this precludes the possibility of a set of political or ethical reasons for judges to either abdicate from their position and/or engage in civil disobedience or resistance.

${ }^{22}$ Ibid.
} 
measure of self-satisfaction or voyeuristic pleasure. ${ }^{23}$ For Weil, the efforts of holding one's attention on a subject, while actively and conscientiously resisting the slide into more pleasurable (or simply less agitating) emotional states, constituted an ethic. ${ }^{24}$ A disciplined resistance was therefore necessary to contend with those habits of thought that worked to obstruct the practice of paying attention to the other (or which facilitated only a selective sort of attention to certain others). This section broadly outlines two different ways in which judicial efforts at paying attention to the claimant might go awry such that the practice would amount to something akin to a false or anti-attention. More perniciously, it suggests that some judicial efforts might result in a publicly announced, and self-satisfied, claim to attention, where the situation and perspective of the other had been wholly obscured, colonised, misread or glossed over. The forms of false or anti-attention highlighted in the second case flow from the failure to recognise empathy's structural selectivity, and vulnerability to bias and stereotype. In both cases, a disciplined resistance to a known tendency to err requires judges to practice a politics of attention that puts emotions to work in their reasoning through a constitutional case.

\section{A. The Error of Taking Up Too Much Space}

Sometimes I turn, there's someone there, other times it's only me.

Bob Dylan, 'Every Grain of Sand' (1981)

Robert Solomon describes some emotions as having an intersubjective focus, meaning that they aim at an understanding that sits, in a sense, somewhere between the person experiencing the emotion and its subject. ${ }^{25}$ Solomon offers pity as an example of such an emotion, and uses this criteria of intersubjectivity to illustrate how ill-versions of the emotion might arise. If the focus of pity, for example, moves too close to the self and away from its subject, it risks becoming narcissistic and/or self-indulgent. ${ }^{26}$ If it moves too far away from the self, the suffering of another might fail to register as it should or might have, causing one, at times, to be obtuse, heedless, hard-hearted or cruel. ${ }^{27}$ This view echoes in John Berger's 'Photographs of Agony', where Berger emphasises the politics of an attention that tends to slide back to the self. ${ }^{28}$ Berger writes how the mind can move inwards to wrestle with questions of moral inadequacy after witnessing a

\footnotetext{
${ }^{23}$ Weil (1956).

${ }^{24}$ Ibid. See, also, Murdoch (1993).

${ }^{25}$ Solomon (2003), 223.

${ }^{26}$ Ibid.

${ }^{27}$ Where the affective component of pain and concern is traded for pleasure, the suffering of others could be met with a form of gawking or titillation. See White (forthcoming).

${ }^{28}$ Berger (1980).
} 
photograph depicting anguish or horror, in a process that effectively transmutes the reality of the other into a private, general and abstract, existential question that remains far removed from the concrete political realities that precipitated the war, the attack, the mass drowning, the famine, etc. Where, for Berger, angst felt by the witness does result in action, it is invariably token if it is aimed at relieving an internal emotional or psychic discomfort as opposed to work aiming at political recognition, confrontation or resistance. ${ }^{29}$

In each of these instances, the commitment to seeing the other as a distinct other that is situated in time and place and worthy of attention, gets obscured by self-serving mental processes that result in a form of inward-focused, false or anti-attention. Solomon's criteria of intersubjectivity helps elucidate this error as the error of the self taking up too much space. Here we see clearly how this error of attention is bound up with an error of recognition. Peter Goldie's work on the ironies and inconsistencies embedded in various conceptions of empathy offers further contour. Empathy is not our practice of interest, and much has been written querying whether empathy is better cast as an emotion, as opposed to a cognitive skill. ${ }^{30}$ Nothing turns here on the conclusion, though a form of empathy motivated by respect and concern, interest or awe, might satisfy a definition of emotion that required an affective component, and would present as a facet of this idea of attention that we've been working towards as it concerns an affectively charged political desire to recognise and learn something about the other. ${ }^{31}$

Goldie distinguishes between a conception of empathy that involves a form of perspective-shifting, from one that aims at an 'in his shoes' position-taking. ${ }^{32}$ While Goldie's work does not address judicial reasoning, we can extrapolate from his analysis to note several ways in which judicial attempts at empathy might backfire. A perspective-shifting empathy would see a judge attempting to enter the head of the individual alleging a rights violation, ('what is it like to be this other person'), whereas an 'in his shoes' form of empathy would have judges attempting to place themselves in the same position as the claimant ('what would I have done in this situation'). ${ }^{33}$ Goldie argues that the first category of 'empathetic

\footnotetext{
${ }^{29}$ Ibid.

${ }^{30}$ See Kind (2020) (chapter ten in this volume). See also White (forthcoming).

${ }^{31}$ Peggy Cooper Davis writes: ‘... how easy it is, even for people with the most egalitarian intentions, to slip into imagining a political institution or community in terms of its more affluent and powerful sectors ... Assumption of a superordinate perspective is, of course, not only easy but also deeply consequential. It is important, but not often difficult, to avoid fallacious reasoning in public discourse. The difficult and often more consequential moves are made in the construction of premises rather than in reasoning from them. And a great deal turns on whether those premises are chosen from a subordinate or a superordinate perspective.' Cooper Davis (2009), 1378-79.

${ }^{32}$ Goldie (2011), 302.

${ }^{33}$ Goldie later introduces a third conception that involves an 'imagining how it is' for another person, which would have the judge maintain their position while aiming to pay dedicated attention to the features of another's situation. As Goldie stresses, however, this form of imaginative thinking requires an intimate knowledge of the other person (knowledge of them as a unique, almost idiosyncatic other), an intimacy that seems wholly out of reach in the context of ajudication. Ibid.
} 
perspective-shifting' is unworkable beyond simple cases $^{34}$ given that it is a category that is 'conceptually unable to operate with the appropriately full-blooded notion of first-personal agency that is involved in deliberation. ${ }^{35}$ This suggests a further normative problem concerning the assumption that one might easily take over the thinking of the other, presuming an ease of access to their mind, reservoir of experiences, and ways of seeing. The idea that one might help oneself so easily to the perspective of another suggests a lack of humility, and/or curiosity about the other, which are ways of thinking that appear anathema to a genuine inquiry into the impact of a law on the rights claimant. For, if the person in the well of the court is so easily understood, and their processes of thinking so replicable, they wouldn't need to be listened to as the source of information about the effects of a law - and this seems contrary to the respect that is meant to be attributed to the claimant under our constitutional systems of interest. This also stands in explicit tension with the emerging jurisprudence in discrimination law that stresses both that laws can have disparate impacts on individuals and groups, and that facially neutral laws can violate equality rights where they serve to exacerbate existing vulnerabilities for historically marginalised persons and communities. ${ }^{36}$

Perspective-shifting empathy as a model for judicial reasoning seems to offer an insufficiently complex picture of the person for it assumes that there are no deep or difficult-to-access differences among the experiences of persons or groups under an impugned law. A related objection exists for the category of the in his shoes' form of empathising, which risks minimising the politics and privilege of imagining it possible to catapult one's self into the situation of another person or group under law, while claiming a steadfast ability to read the relevant context. Prescriptions for judicial empathy must attend to the structural features of the judicial role, including the social, political and economic power of judges, their standing, immunities and hindsight privilege. Otherwise, such prescriptions serve only to encourage impervious-to-stakes, flippant and fantasy-rich, imagined excursions into the lives of others under law. For example, it was not long ago that the Canadian Judicial Council recommended the unseating of a judge who, during the course of a rape trial, attempted to put himself in the position of the victim, offering her a number of offensive stereotypes and comments about what he might have done in the same situation to resist sexual violence (ignoring, amongst other things, her physical vulnerability vis-à-vis her attacker). ${ }^{37}$ This example

\footnotetext{
${ }^{34}$ Goldie uses the term, 'base cases' to refer to those 'where the empathizer has the same psychological dispositions (including character and personality) as the target; where there are no non-rational influences on the target's thinking; where the target is not confused about his state of mind; and where the target is not psychologically conflicted in his deliberations'. Ibid.

${ }^{35}$ Ibid.

${ }^{36}$ See eg Moreau (2010) and Moreau (2007).

${ }^{37}$ In the Matter of an Inquiry Pursuant to s. 63(1) of the Judges Act Regarding the Honourable Justice Robin Camp Report and Recommendation of the Inquiry Committee to the Canadian Judicial Council.
} 
highlights some of the pernicious consequences of an unserious form of 'in his shoes' empathising. ${ }^{38}$

Under either of the forms of empathy outlined above, the legal demand to confront the claimant as a distinct 'other' worthy of respect and attention is both diluted and obscured. What is needed as antidote is a practised politics of attention which includes the use of emotions to paint the other as worthy of a certain inviolability, and/or gravity. This entails the conscientious wielding of emotions like respect and awe to give adequate heed to the other, instead of basing one's legal findings on what one thinks they might have thought, felt or done under the same circumstances.

There is a related error that results in the claimant not only being obscured in the process of judicial reasoning, but having selective excerpts of her experiences co-opted into the service of a pre-conceived narrative schema. In the mid-1950s, the poet and literary critic Randall Jarrell found himself lamenting the late poetry of Wallace Stevens. A short piece in Jarrell's collection of essays, Poetry and the Age ${ }^{39}$ found Jarrell at last able to characterise the error he felt emerging in Stevens' late work. Jarrell charged Stevens with moving towards a form of 'philosophical poetry' - Jarrell's (derogative) term for using descriptions of things or persons in the world in the service of positing a general truth. The error for Jarrell consisted in the failure to be open and responsive to specificity, which had the effect of rendering the self immune from being called up, or changed via a confrontation with a particular person, event, object, or place. Jarrell thought this was a difficult to error to spot, for it consisted in well-crafted descriptions of things (persons, events, object or place) that weren't, in the end, about them being real or seen or confronted in the world, but, rather, about their being co-opted and fashioned into a broader narrative account. The objective of the description was to select and use particular facets of the subject in the service of positing a general theoretical understanding. Jarrell offered the following description:

But Stevens has this weakness - a terrible one for a poet, a steadily increasing one in Stevens - of thinking of particulars as primarily illustrations of general truths, or else as aesthetic, abstracted objects, simply there to be contemplated; he often treats things or lives so that they seem no more than generalizations of an unprecedentedly low order. But surely a poet has to treat the concrete as primary, as something far more than an instance, a hue to be sense, a member of a laudable category - for him it is always the generalization whose life is derived, whose authority is delegated. ... ${ }^{40}$

Jarrell's characterisation of this move is useful for delineating a difficult-topinpoint ill-version of attention in judicial reasoning. For Jarrell, a 'philosophical

\footnotetext{
${ }^{38}$ For further critiques of our ability to read the emotions of others. See eg Bandes (2016); Feldman Barrett (2017). On the difficulty of reading emotions over time and place, see Williams, Shame and Necessity (2008); Cotter (2017).

${ }^{39}$ Jarrell (1955).

${ }^{40}$ Ibid, 124-25.
} 
poetry' sees the poet no longer paying the sort of attention required by the practice at hand. The insistence on using a specific instance to draw out a general theory entails a failure to remain open and attentive to the actual subject. Reasoning of this sort is dismissive of the independent existence and status of the subject. It also, for Jarrell, constitutes a betrayal of craft. In legal reasoning, a corollary of this error would consist in a judge selectively employing some of the claimant's own evidence to confirm a previously held general understanding of a purview of a right, for example, without ever having been open to a serious reconsideration of the legal matters before the court. We might think here of a judge dutifully displaying in the reasons for judgment some of the claimant's evidentiary record, or even drawing upon some of the claimant's own language knowing on a pragmatic level that this could render a judgment less prone to appeal, bolster its legitimacy, or offer the impression of understanding, rigour and/or compassion. Even more mundanely, judges might also include this sort of mimicking language in their reasons because they understood it to be part of their own technical practice of judgment writing. Jarrell's identification of this error of attention isn't dependent on a malicious will but is, in fact, generally committed in the service of one's own (distorted) sense of craft. It is imperative to notice here how language use masks the error, making it particularly challenging, if not nearly impossible, to discern. As such, judicial reasoning requires a politics of attention to counteract this well-hidden but nevertheless pernicious form of a false attention. In the absence of a politics of attention - that is, a form of attention concerned with its own principled distribution - there is only a rhetoric, a claim, and an illusion of attention.

A form of judicial attention that actively cultivated a sense of respect, or even awe towards the claimant as a legal subject might work to resist this pull to obscure, erase or co-opt their perspective into a pre-conceived narrative. Cynical judges who say to themselves, 'I've seen this before. I've seen you (as a type of person) before', betray core legal value commitments, and they do so by failing to pay attention to the subject in their legal reasoning practices. In his Dewey Lecture at Harvard Law School, Thomas Nagel came close to describing the phenomenology of this politics of attention that we are piecing together here, when he said that 'Each person with whom I interact presents me with the same stubborn and impenetrable moral surface that I present to him .... ${ }^{41}$ This points to the need to develop practices of legal reasoning that actively reinforce the standing, respect and/or dignity that the law has attributed to the claimant. The two legal rationales for judicial attention are important here. Were empathy only required for epistemic reasons relating to how the individual or group was impacted by the impugned law then the judge could be permitted to sidestep any real attempt to take the claimant seriously where information about the law's impact was thought to be otherwise available.

\footnotetext{
${ }^{41}$ Nagel (2015).
} 


\section{B. Errors of Application}

The preceding section analysed the need to course correct against a series of errors that judges might make in their attempts to pay the required form of attention to the claimant in the hearing of a constitutional law case. Empathy can be cast as a facet of attention and this section considers the tendency to empathise unevenly, and selectively, and how this poses deep challenges for legal reasoning in a constitutional system committed to recognising something akin to the equal dignity of persons. ${ }^{42}$ Most working definitions suggest that empathy involves the attempt to enter the mind of another, or to move closer to another's experience of the world. ${ }^{43}$ Empathy can be defined as a facet of attention when it is motivated by an affective respect or concern for the other. It is this form of empathy that can be said to facilitate the required practices of legal reasoning in the constitutional systems outlined above $^{44}$ as it reinforces the respect owed to the claimant, and cultivates a serious interest in lived experiences under the impugned law. ${ }^{45}$

While this form of judicial empathy is required to adjudicate rights, ${ }^{46}$ it is a practice of legal reasoning that is prone to errors of application. ${ }^{47} \mathrm{~A}$ politics of attention is needed to remedy the structural selectivity of empathy. This requires the work of a series of emotions (respect, curiosity, concern) to animate, motivate and sustain the legal value-based commitments to seeing all claimants as deserving of attention, and capable of possessing valuable information about the impact of the impugned law.

How empathy is triggered is an old question. Over 2500 years ago, in Book VII of his Problemata, Aristotle set down a puzzle for empathy and imagination when he queried:

Why is it that when we see anyone cut or burned or tortured or undergoing any other painful suffering, we share mentally in his pain? Is it because nature is common to us all, and it is this which shares in the sufferer's pain, when we see any of these things happening to him, through kinship with him? Or is it because, just as the nose and hearing

\footnotetext{
${ }^{42}$ For a powerful examination of a failure to accord equal dignity to all persons under law, see Blum (2020) (chapter seven in this volume).

${ }^{43}$ Ibid.

${ }^{44}$ If empathy is defined solely as the ability to know or predict the minds of others, then there is no definitional component that rules out calling the sociopath, or the skilled emotional manipulator, empathetic. For deeper discussion on this, see Hansberg (2020) (chapter nine in this volume). Some philosophers of emotion reject the categorisation of empathy as an emotion for this reason. The posited working conception above contains an affective dimension, as well as a constitutive desire (to learn about the other out of respect and concern) and, as such, could be plausibly categorised as an emotion (see Solomon, 1977; Solomon, 2003), though nothing in the overall argument turns on this.

${ }^{45}$ Whether this bears out as a matter of empirics is a separate question. The aim of this chapter is to clarify the emotional elements of the prescribed legal reasoning.

${ }^{46}$ Forwarding a related claim, see Zipursky's wonderful chapter on compassion and austerity in judicial reasoning (2020) (chapter four in this volume).

${ }^{47}$ Nevertheless, empathy remains a regular aspect in judicial reasoning. See Kind's excellent chapter (2020) (chapter ten in this volume).
} 
according to their faculties receive certain emanations, so also the sight does the same as the result of things pleasant and painful?" 48

This line of questions raises a series of others. Must a recognition of kinship or equality always precede the 'sharing of another's pain,' or might the witnessing of another's pain instigate or facilitate this recognition of kinship or equality. This is a critical sequencing question. Lynn Hunt has argued for the latter position, suggesting that, over time, literary depictions of pain and suffering have worked to generate more inclusive conceptions of justice through empathy. ${ }^{49}$ Hans Joas resists this view by using historical examples to illustrate how the pain of 'the other' remained unseen and un-affecting prior to the recognition that they were sacred or equal..$^{50}$ While these views needn't be mutually exclusive, the productive potential of empathy in the law rests on the sequencing of pain and recognition that the emotion is presumed to entail. A judge who empathised only with those claimants whom they - consciously or unconsciously - understood to be part of their in-group would be in serious error. ${ }^{51}$ As Martha Nussbaum writes,

Humanity does not automatically reveal itself to strangers. No placard hung on the front of a fellow citizen announces that this one is a full-fledged human being (and not a vile bug or piece of refuse). Seeing the shape of a human being before us, we always have a choice to make: will we impute full equal humanity to that shape, or something less? Only by imagining how the world looks through that person's eyes does one get to the point of seeing the other person as a someone and not a something. ${ }^{52}$

Critics have pointed to features of empathy that make it unsuitable for use in political decision-making, and from these critiques we can extrapolate several concerns with the use of empathy in judicial reasoning. ${ }^{53}$ Empathy may be too intimate ${ }^{54}$ an emotion to expect in such a formal setting, or where there are such clear power dynamics at play. Paul Bloom has argued that the structure of empathy makes it a poor guide for social policy, given that it operates most easily when the other is thought to be like us or is found attractive (ie criteria that would clearly be anathema to legal commitments to equality). Judges would undermine legal commitments to equality were they to feel only pity, compassion or moral outrage over the unjust treatment of the claimant because the judge felt a kinship towards them. ${ }^{55}$ It is

\footnotetext{
${ }^{48}$ Aristotle in Barnes (1984), 1371.

${ }^{49}$ Hunt (2007).

${ }^{50}$ Joas (2013).

${ }^{51}$ This echoes the concern with deep-seated prejudice, which is generally accompanied by emotions of contempt or enmity. Beliefs and extraneous emotions that contradict core legal values must be excluded, to the extent possible, from judicial reasoning that is committed to equal concern and respect. Whether this is, in fact, achievable is a pressing question. On unconscious bias, see Lane, Kang and Banaji (2007).

${ }^{52}$ Nussbaum (2004), xvii.

${ }^{53}$ See eg Bloom (2014).

${ }^{54}$ See Leighton (2007).

${ }^{55}$ Recall the outrage over the sentencing of Stanford swimmer Brock Turner: see Koren (2016). The sentencing judge in that case found himself empathising with the accused (Justice Aaron Persky of the Santa Clara Superior Court was also a Stanford alumnus and gave Turner a markedly reduced sentence,
} 


\section{Emily Kidd White}

often a concern over the partiality of empathy, and other emotions, that underlies calls to remove their influence from judicial reasoning. Such concerns are valid but the prescription is misleading. We would not, for example, want a judge to feel nothing when confronted with evidence of a rights violation. ${ }^{56}$ Rather, the aim is to establish a boundary that excludes those emotions that do not easily extend to all persons, and to cultivate political practices that work against certain habits of thought and feeling that undermine commitments to equal protection under the law. Despite its structural flaws, the right version of empathy plays an indispensable role in judicial reasoning because it cultivates and reinforces a serious interest in the lived experiences of others under the law. ${ }^{57}$ What is needed, then, is an affectively-charged, serious attempt at understanding that aims at recognition to actively resist the errors of co-option, obstruction and selectivity outlined above. This requires judges to summon, construct and/or revive an emotional state necessary for reasoning through constitutional rights case before the court. Given the pull of these errors, a neutral emotional state will result in legal reasoning that is prone to error, and which violates its own legal-value based commitments to showing equal respect and dignity to persons. Margalit stresses the problem of indifference in moral life, and its evil. He writes: 'There is not so much banality of evil as banality of indifference. ${ }^{58}$ Martha Nussbaum voices a related concern. In her book Poetic Justice, she argues that we need to work to cultivate the necessary empathy to practise justice in a world full of division, hatred and violence. ${ }^{59}$ Both views highlight the need for the presiding judge to exercise empathy politically, that is, conscious of distribution and conscientiously, in the judicial assessment of the harms caused by a government act or legislative scheme.

Evidence of humiliation, exclusion, pain and degradation should alert the judge and call up her attention. A cool cynicism, apathy or numbness would clearly betray the respect owed to the claimant and the severity of the alleged rights violation. In a distinct but related vein, a judge who never felt anger, pity, compassion, respect or indignation in response to evidence of a rights violation could not be said to be reasoning in line with legal values that emphasised equal concern and

which seemed inconsonant with the crime of rape and representative of the privilege of confronting the criminal justice system as a white, elite male). As such, empathy stood in strong contrast to the commitment to equal treatment before the law. This case highlighted some of the pernicious features of empathy that are well documented in Paul Bloom's book (that we empathise most easily with those who we consider most like us, etc). See Bloom (2016). This case is also discussed in Elgin (2020) (chapter three in this volume).

${ }^{56}$ Neutrality can signal a lack of respect or understanding. See, famously, Aristotle, 'Nicomachean Ethics', in Barnes (1984), 1104b 15-30. See White (2014) and Zipursky (2020) (chapter four in this volume).

${ }^{57}$ One of Bloom's central criticisms of the use of empathy in the construction of social policy is that it 'is narrow; it connects us to particular individuals, real or imagined, but is insensitive to numerical differences and statistical data'. Note that this concern is somewhat neutralised in the judicial setting, where the focus is properly placed on an individual's experience under the law. See Bloom (2014).

${ }^{58}$ Margalit (1996).

${ }^{59}$ Nussbaum (1997). 
respect. The same is true for judges who never experience these emotions with respect to certain groups of persons, delineated perhaps by race, socio-economic class, ethnicity, gender, sexuality, citizenship, age, physical ability, etc. The failure to respond emotionally to a legal wrong suffered by a certain group demarcated as the 'other' has long been attributed to judgments about differential status. ${ }^{60}$ One of the harms of diminishing the humanity of a group is that this works to block feelings of sympathy, solidarity, empathy or compassion with the victims, and so too feelings of indignation or moral outrage at the law over its unjust treatment of that group. ${ }^{61}$ A judge's failure to recognise and respond to the pain and suffering of others either in general or with respect to a particular group is evidence that their reasoning betrays legal commitments to attribute a full and equal humanity to all persons. ${ }^{62}$

\section{Addressing an Objection to a Judicial Politics of Attention}

We have thus far outlined a series of errors that judges might make when they seek to pay attention to a claimant in a constitutional law case. While prone to error, there are nevertheless legal reasons for judges to pay a particular form of attention to the claimant. An objection follows from this prescription - what are the implications for the rule of law where if the judge succeeds in paying attention to the claimant? ${ }^{63}$ Won't the proscribed judicial politics of attention render the claimant's subjective experience of the law determinative on the question of a potential rights violation, thereby undermining rule of law type commitments (that the law be general, knowable in advance, prospective, etc). This charge oversimplifies the role of judicial attention in judicial reasoning. In a constitutional rights case, the objective of judicial reasoning is to determine whether the impugned law violates the claimant's constitutionally guaranteed rights. An affectively rich practice of judicial attention facilitates this inquiry, and while it pays heed to the emotions and the subjective experience of the claimant, it renders neither determinative of the constitutional question at hand. ${ }^{64}$

Emotions can play positive epistemic roles in judicial reasoning ${ }^{65}$ by gripping and focusing the attention ${ }^{66}$ of the presiding judge or judicial panel, thereby

\footnotetext{
${ }^{60}$ See eg Garland (1993).

${ }^{61}$ See eg Waldron (2012b). See also, the Supreme Court of Canada's reasoning on hate speech in Saskatchewan (Human Rights Commission) v Whatcott, 2013 SCC 11.

${ }^{62}$ For an in-depth discussion on this, see White (2014).

${ }^{63}$ See Elgin (2020) (chapter three in this volume) for a rich discussion on impartiality and impersonality in legal judgement vis-à-vis the rule of law criteria of generality.

${ }^{64}$ White (2014). See also Zipursky's authoritative work on compassion in judicial reasoning (1990).

${ }^{65}$ I am grateful to Thomas Nagel for pressing for this clarification.

${ }^{66}$ Brady (2013), 5.
} 


\section{Emily Kidd White}

prompting a re-evaluation of the impugned law or government action. While it is not the case that a claimant's subjective experience of a rights violation will ever be constitutive of a legal rights violation, a claimant's evidence and testimony can work to capture the attention of the judge or judicial panel and prompt them to reappraise their understanding of the situations on the ground that should engage existing rights protections. A claimant's emotions can, at times, work to initiate a related emotional response in the judge, which 'can motivate the search for reasons that bear on the accuracy of their own initial assessment of some object or event, and thus motivate the rational reappraisal or reassessment of that object or event. ${ }^{67}$ An emotion, for example, might begin with a strong physiological response - such as the quickening heartbeat that is characteristic of fear - that works to focus critical attention on the object of that emotion, inviting a process of cognitive reflection ${ }^{68}$ that can work to diffuse, intensify or change the emotion (we can think of fear moving to indignation, or laugher upon further reflection, for example). A person who has been taken to a secondary screening room at an airport Customs and Immigration office and subjected to an arduous and demeaning round of questioning might shake, perspire and feel nervous or fearful at the time. Afterwards, however, this same person might come to have a different set of emotional reactions, such as anger or indignation, while thinking about this episode, its particular features and politics, and perhaps even the emotions that she experienced while undergoing it. ${ }^{69}$ As Peter Goldie suggests, we can think both internally and externally about the emotional import of a past event. ${ }^{70}$ As in our example, moving across these categories (from an internal to an external reference point) can cause the emotional response to shift. This reflection and processing is motivated by the very structure of the emotion. Emotions aid thinking in this way by setting up internal and external viewpoints. Similarly, we can have different emotional responses to an event depending on whether we take a broad or narrow view of it. ${ }^{71}$ An occurrence might be more painful (or irritating, or pleasing), for example, when we recognise it to form part of a pattern of interactions. Robert Solomon has likened this reflective feature of emotion to a camera lens that is capable of different resolutions. Looking at law, then, through a historical lens, we can see how a claimant's depiction of humiliation and/or degradation under law may claim a history, rationality and validity that another instance does not. ${ }^{72}$

We might also think of the ways in which the emotions experienced by the judge (or by individual judges sitting on a panel) hearing a case might be mediated

\footnotetext{
${ }^{67}$ Ibid.

${ }^{68}$ See eg Robinson (2005).

${ }^{69} \mathrm{I}$ do not wish to give the impression that there won't be variations - wide ones, even - in how this example might affect different groups in a society. The interaction might rationally present as a threat to a group that has been historically marginalised and/or victimised by public officials, while not experienced directly as such by others.

${ }^{70}$ Goldie (2009).

${ }^{71}$ Ibid.

72 'Debo justificar lo que me hiere' (Trans. by Rocio Lorca: I have to justify what wounds me). This is the first line on Jorge Luis Borges's headstone. Cited in Berger (2006). See also Cooper Davis (2009).
} 
or unmediated. ${ }^{73}$ That is, the emotion's object might be either the factual features of the claimant's situation under the impugned law (unmediated) or the claimant's own subjective experience of that same situation, including the claimant's emotional experiences (mediated). With respect to the latter, the judge will be concerned with the subjective experience of the claimant, and may focus, for example, on the 'testimony' documenting the humiliation and pain that flowed from the legal wrong of the alleged rights violation. ${ }^{74}$ This does not mean that the emotions of the claimant are in any way determinative of a rights violation. ${ }^{75}$ The version of empathy outlined in this chapter serves as an evidence-gathering skill, that supports the construction of the relevant factual matrix before the court, and assists in interpreting the constitutional right in question (as well as justified limits to that right).

Consider the form of a trenchant dissent, written against a court majority who, in the opinion of the dissenting judges, failed to see something imperative in the determination of a rights case. As Terry Maroney writes, dissenting opinions written in this register are legion. ${ }^{76}$ While a dissenting judge or judicial panel might feel moved to indignation for a variety of reasons, it is nevertheless useful to explore some distinctions. We could, for example, distinguish between instances where the dissenter was indignant over (1) the belief that the majority failed to altogether grasp the harm or wrong experienced by the claimant in a rights case (set off, perhaps, by the majority's cold appraisal of certain facts), from those with their roots in (2) the belief that the majority, while grasping the harm or wrong experienced by the claimant, nevertheless failed to find that a right had been violated. ${ }^{77}$ In both cases, the absence of certain emotional reactions in the judicial reasoning reveals, in the view of the dissenters, an absent or poorly applied legal value. In the first instance, the failure to react with certain emotions to the evidence in the case calls into question the majority's understanding of the relevant factual matrix, as interpreted through the lens of the governing legal values (this brackets questions of relevance and admissibility). ${ }^{78}$ The reference to legal values here is intended to set aside those instances in which a dissent appears to abandon the idiom of law altogether, writing in indignation in a purely ethical register, for example, to

\footnotetext{
${ }^{73}$ I am here using Del Mar's useful distinction between mediated and unmediated emotions. Del Mar (2017), 145-46. For a deep enquiry into the role of artefacts and imagination in legal reasoning, see Del Mar (2020) (chapter thirteen in this volume).

${ }^{74}$ Some have argued that it is better to describe empathy, not as an emotion (where it does not involve a 'feeling with'), but as a cognitive process of understanding the emotional states of others. See eg Coplan and Goldie (2011) and Goldie (2011).

${ }^{75}$ See also Elgin (2020) (chapter three in this volume).

${ }^{76}$ See Maroney (2011), 629.

${ }^{77}$ A third scenario would occur where a dissenting judge feels moved to indignation believing that the majority was improperly swayed by the evidence to find a rights violation where one did not exist.

${ }^{78}$ Here the assumption is that the emotion-inducing evidence is relevant to the legal determination at hand.
} 
admonish the majority's reasoning. What remains is the charge that the majority would have apprehended the relevant evidence differently had it properly applied the governing legal values. Another sort of epistemic function that emotional reactions serve is more pronounced in the second scenario, where we imagine the dissent's indignation flowing from the majority's failure to interpret the right at issue in light of the evidence. This does not ground the interpretation of the right in the emotional reaction; rather, it highlights precisely how the experience of the emotion pushes the judge or judicial panel to interpret the purview of the right in question in line with the guiding legal value. ${ }^{79}$ The strong emotional reaction of the judge prompts a searching and sustained inquiry into whether the law or government act violates the right in question as interpreted through the lens of the guiding value. Judicial attention fulfils an epistemic function here by pressing the judge to see if the impugned law or government act violates a constitutional right, motivating the re-examination of the purview of the right. This is the second epistemic function that emotions fulfil in judicial reasoning - the flagging, attentioncapturing function.

\section{Conclusion}

Legal commitments to equality and respect require judicial reasoning practices that reflect a politics of attention that reinforces a broad and deep, curious and concerned understanding of how the impugned law has impacted an individual or group. This judicial politics of attention works to critically engage with and press upon the boundaries of the category of what constitutes a rights violation. An affectively charged judicial politics of attention draws on emotions to animate and reinforce legal commitments to equality and dignity, and works to attribute a gravity ${ }^{80}$ and inviolability to the claimant. In Nagel's terms, they work to cloak the claimant with an 'impenetrable moral surface' such that judicial efforts to understand a case don't obscure, or run roughshod over, a claimant's rightful legal standing. An unaffected, banal, or cynical read of the claimant will be insufficient to guard against the habits of thought and feeling outlined above that would lead judges to obscure, dismiss or selectively empathise with the claimant.

A political attention concerns itself with a principled distribution of attention, and draws on emotions to generate and hold steady the respect owed to the claimant under the strictures of the constitutional order. Where a judge fails to consciously cultivate a political attention, they risk offering only a firm of false or anti-attention that undermines legal values and legal commitments. Calling up the right emotional frames for reasoning through a case is difficult and careful work. ${ }^{81}$ Emotional motivation cannot be

\footnotetext{
${ }^{79}$ See Zipursky's seminal work on this (1990).

${ }^{80}$ See eg Halbertal (2015).

${ }^{81}$ See White (forthcoming).
} 
abandoned simply because it is difficult to get right, nor in the face of political contestation over what laws or government acts constitute a rights violation. Iris Murdoch held that curiosity was a matter of morality, agitating us away from certainty toward truths previously unseen. Recognising, through adjudication, instances of humiliation, exclusion and degradation made possible under law is an urgent and critical matter. The normative foundations of our constitutional systems of interest set this objective for legal reasoning. In light of this, we cobble together pieces for a judicial politics of attention, and take seriously our task of setting to light the work of emotions (like respect, curiosity and humility) in resisting the pervasive forms of anti-attention that would prevent a judge from seeing what the law has asked them to look for.

\section{References}

\section{Cases}

Saskatchewan (Human Rights Commission) $v$ Whatcott, 2013 SCC 11

United States $v$ Kras, 409 U.S. 434, 460 (1973)

\section{Articles and Books}

Abrams, K and Keren, H (2010) 'Who's Afraid of Law and the Emotions?' Minnesota Law Review 94.

Aristotle (1984) 'Nicomachean Ethics' in J Barnes (ed), The Complete Works of Aristotle (Bollingen series, II; Princeton, Princeton University Press), 1729.

Bandes, S (2016) 'Remorse and Criminal Justice' Emotion Review 8(1).

Bandes, S (1999) The Passions of Law (New York, New York University Press).

Barrett, L (2017) ‘The Law’s Emotion Problem’ New York Times Sunday Review (March 11). Berger, J (2006) Here Is Where We Meet: A Story of Crossing Paths (Vintage).

Berger, J (1980) About Looking (New York, Pantheon Books).

Bloom, P (2016) Against Empathy: The Case for Rational Compassion (New York, Ecco Press).

Bloom, P (2014) 'Against Empathy' Boston Review: A Political and Literary Forum. Available at http://bostonreview.net/forum/paul-bloom-against-empathy.

Blum, L (1980) 'Compassion', in AO Rorty (ed), Explaining Emotions (Los Angeles, University of California Press).

Blum, L (2020) “Black Lives Matter”: Moral Frames for Understanding the Police Killings of Black Males' in A Amaya and M Del Mar (eds) Virtue, Emotion and Imagination in Law and Legal Reasoning (Oxford, Hart Publishing).

Brady, M (2013) Emotional Insight: The Epistemic Role of Emotional Experience (New York, Oxford University Press).

Breyer, S (2013) 'On Reading Proust', New York Review of Books available at https://www. nybooks.com/articles/2013/11/07/reading-proust.

Cooper Davis, P (2009) 'Responsive Constitutionalism and the Idea of Dignity', University of Pennsylvania Journal of Constitutional Law 1373. 


\section{Emily Kidd White}

Coplan, A and Goldie, P (eds) (2011) Empathy: Philosophical and Psychological Perspectives (Oxford, Oxford University Press).

Corso, L (2014) 'Should Empathy Play any Role in the Interpretation of Constitutional Rights?' 27(1) Ratio Juris 94.

Cotter, H (2017) “'A World of Emotions” in Greek Art Unmasks theStony Faces' New York Times (23 March).

Del Mar, M (2017) 'Imagining by Feeling: A Case for Compassion in Legal Reasoning', 13(2) International Journal of Law in Context 143.

Del Mar, M (2020) 'The Legal Imagination: Individual, Interactive and Communal' in A Amaya and M Del Mar (eds) Virtue, Emotion and Imagination in Law and Legal Reasoning (Oxford, Hart).

De Sousa, R (1987) The Rationality of Emotion (Cambridge, The MIT Press).

Domselaar, van, I (2020) 'All Judges on the Couch? On Iris Murdoch and Legal DecisionMaking' in A Amaya and M Del Mar (eds) Virtue, Emotion and Imagination in Law and Legal Reasoning (Oxford, Hart Publishing).

Elgin, C (2007) 'Understanding the Facts' 132 Philosophical Studies 33.

Elgin, C (2020) 'Impartiality and Legal Reasoning' in A Amaya and M Del Mar (eds) Virtue, Emotion and Imagination in Law and Legal Reasoning (Oxford, Hart Publishing).

Gardner, J (2008) 'The Logic of Excuses and the Rationality of Emotions' (35) Oxford Legal Studies Research Paper.

Garland, D (1993) Punishment and Modern Society: A Study in Social Theory (Chicago, University of Chicago Press).

Goldie, P (2009) 'Narrative Thinking, Emotion, and Planning' 67(1) The Journal of Aesthetics and Art Criticism 97.

Goldie, P (2010) The Oxford Handbook of Philosophy of Emotion (Oxford, Oxford University Press).

Goldie, P (2011) 'Anti-Empathy' in A Coplan and P Goldie (eds) Empathy: Philosophical and Psychological Perspectives (Oxford, Oxford University Press) 302.

Halbertal, M (2015) 'Three Concepts of Human Dignity' The Dewey Lecture at the University of Chicago Law School.

Hansberg, O (2020) 'Emotional Intimacy' in A Amaya and M Del Mar (eds) Virtue, Emotion and Imagination in Law and Legal Reasoning (Oxford, Hart Publishing).

Hunt, L (2007) Inventing Human Rights: A History (New York, WW Norton \& Co).

Huscroft, G, Miller, BW and Webber, G (2014), Proportionality and the Rule of Law: Rights, Justification, Reasoning (New York, Cambridge University Press).

Jarrell, R (1955) Poetry and the Age (London, Faber).

Joas, H (2013) The Sacredness of the Person: A New Genealogy of Human Rights (Washington, Georgetown University Press).

Lane, KA, Kang, J and Banaji, MR (2007) 'Implicit Social Cognition and the Law' (3) Annual Review of Law and Social Science 427.

Kind, A (2020) 'Empathy, Imagination, and the Law' in A Amaya and M Del Mar (eds) Virtue, Emotion and Imagination in Law and Legal Reasoning (Oxford, Hart Publishing).

Koren, M (2016) 'Why the Stanford Judge Gave Brock Turner Six Months' The Atlantic (17 June).

Kretzmer, D and Klein, E (2002), The Concept of Human Dignity in Human Rights Discourse (The Hague, Kluwer Law International).

Leben, S (2011) 'An Expectation of Empathy' 51(1) Washburn Law Journal 49.

Leighton, S (1985) 'A New View of Emotion' 22(2) American Philosophical Quarterly 133. 
Leighton, S (2003) Philosophy and the Emotions: A Reader (New York, Broadview Press). Leighton, S (2007) 'On Pity and Its Appropriateness' Religion in Philosophy and Theology. MacCormick, N (1978) Legal Reasoning and Legal Theory (Oxford, Clarendon Press).

Margalit, A (1996) The Decent Society (Cambridge, Harvard University Press).

Maroney, T (2006) 'Law and Emotion: A Proposed Taxonomy of an Emerging Field' 30 Law and Human Behavior 119.

Maroney, T (2011) 'The Persistent Cultural Script of Judicial Dispassion' 99(2) California Law Review 629.

Moreau, S (2007) 'The Promise of Law v. Canada' 57(2) The University of Toronto Law Journal 415.

Moreau, S (2010) 'What is Discrimination?' 38(2) Philosophy and Public Affairs 143.

Murdoch, I (1993) Metaphysics as a Guide to Morals (New York, Penguin Press).

Nagel, T (2015) The Dewey Lecture at Harvard Law School.

Nussbaum, M (1996) The Therapy of Desire: Theory and Practice in Hellenistic Ethics (Princeton, Princeton University Press).

Nussbaum, M (1997) Poetic Justice: The Literary Imagination and Public Life (Boston, Beacon Press).

Nussbaum, M (2001) Upheavals of Thought. The Intelligence of Emotions (Cambridge, Cambridge University Press).

Nussbaum, M (2004) Hiding from Humanity: Disgust, Shame, and the Law (Princeton, Princeton University Press).

Robinson, J (2005) Deeper than Reason: Emotion and its Role in Literature, Music, and Art (Oxford, Oxford University Press).

Schoolman, M(2001)ReasonandHorror:CriticalTheory,DemocracyandAestheticIndividuality (New York, Routledge).

Solomon, R (1988) 'On Emotions as Judgments' 25(2) American Philosophical Quarterly 183.

Solomon, R (1977) The Passions: Emotions and the Meaning of Life (New York, Anchor Books).

Solomon, R (2003) Not Passion's Slave: Emotions and Choice (New York, Oxford University Press).

Waldron, J (2012a) Dignity, Rank, and Rights, M Dan-Cohen (ed) (New York, Oxford University Press).

Waldron, J (2012b) The Harm in Hate Speech (Cambridge, Harvard University Press).

Weil, S (1956) 'The Iliad, or The Poem of Force' 18(2) Chicago Review 5.

White, EK (2014) 'Till Human Voices Wake Us: The Role of Emotion in the Adjudication of Dignity Claims' 3 Journal of Law, Religion and State 201.

White, EK (forthcoming) Emotions in Legal Reasoning (Oxford, Oxford University Press). Williams, B (2008) Shame and Necessity (Berkeley, University of California Press).

Zipursky, B (1990) 'DeShaney and the Jurisprudence of Compassion' 65 New York University Law Review 1101.

Zipursky, B (2020) 'Austerity, Compassion and the Rule of Law' in A Amaya and M Del Mar (eds) Virtue, Emotion and Imagination in Law and Legal Reasoning (Oxford, Hart Publishing). 
